Vol. XXI, No. 4

\title{
Wascana Goose Summers on the Arctic Prairie
}

by R. Thomas Sterling,'Ducks Unlimited (Canada), Saskatoon

Although it is known that the Canada Goose (Branta canadensis) is a relatively common breeder in Saskatchewan (Caldwell, 1963) and that they do not normally breed before their third year, the location of non-breeding birds during the midsummer has remained a mystery. These cne and two-year-old birds have never been found within their known breeding range at this season in the numbers in which they are known to exist.

The resident flock of Canada Geese on the Wascana Marsh : at Regina has been under closer observation than any cther of ccmparable size in Saskatchewan. Fred G. Bard, Director of the Saskatchewan Museum of Natural History (pers. comm., 1963), has noted the annual phenomenon of the disappearance in the spring of a large portion of the wintering birds, with reappearance by early fall. Similar occurrences have been witnessed on other major goose nesting marshes. Flocks of obviously unpaired geese arrive in April shortly after the local breeders and leave again by late May or early June. Since subsequent sightings wculd certainly be made if they remained cn cur prairie or parkland marshes, we have assumed they must travel to isolated areas further north to summer. Ted Jonasson, a Conservation Officer in the Department of Natural Resources of Uranium City (pers. comm., 1963), cn June 6, 1963, noted such a major northward flight of large Canada Geese over the east end of Lake Athabasca. Subsequently, on June 19, A. H. McPherson, Canadian Wildlife Service biologist (pers. ccmm., 1963), noted a major influx of large-type Canada Geese into the Aberdeen Lake region of the Northwest Territories. Previously, large mid-summer moulting concentrations of what were believed to be the larger races of Canada Geese had been noted and recorded by Canadian Wildlife Service personnel and cthers (Clarke, 1937) on the Thelon River, Northwest Territories. There was speculation that the Saskatch- ewan birds might be associated with them.

Dr. I. McTaggart Cowan, Head cf the Department of Zoology, University of British Columbia (1954), repcrted on two juvenile Canada Geese (B.c.moffitti) banded in scuthern British Columbia and subscquently recovered in the Bathurst Inlet area, providing positive proof that these birds at least occasionally did travel to Arctic regions. E. Kuyt, Canadian Wildlife Service biclozist (1962), provided the first firm evidence that the geese moulting $c n$ the Thelon were from the large-type races breeding further south. On June 19, 1960, he captured a moulting goose at approximately $101^{\circ} 48^{\prime} \mathrm{W}, 64^{\circ} 21^{\prime} \mathrm{N}$, which had been banded as a pre-flight young in 1957, at the Bowdoin National Wildlife Refuge, near Malta, Montana.

In July of this year (1963) I conducted some preliminary investigaticns concerning the geese on the Thelon River. Through arrangements made by A. Dzubin, Canadian Wildlife Service biologist with Ducks Unlimited, I had the privilege of joining R. A. Ruttan's Canadian Wildlife Service Barren Ground Caribou tagging crew, located on the Thelon River between Beverley and Aberdeen Lakes. It was planned that I shculd have the opportunity of taking a census of the geese on 150 miles of the river and connected lakes and of collecting some for identification purposes.

On July 12, 1963, the caribou tagging teams combined on a drive in which 500 Canada Geese out of a total of approximately 2000 were caught and banded, at $100^{\circ} 07^{\prime} \mathrm{W}$, $64^{\circ} 33^{\prime} \mathrm{N}$. Twerty-nine previously banded geese were caught in the drive. Ten of these had been banded near Rochester, Minnesota, where B.c.maxima, once thought to be extinct, was recently rediscovered (Kimball, 1963). The remainder had been banded at Oak Point, Lake Manitoba, and on known wintering areas of birds breeding in Manitoba.

Of special interest to Saskatchewan 
